\title{
Influence of knolkhol on quality characteristics of chicken meat balls
}

\author{
Ifrah Khursheed $^{1}$, Julie Dogra Bandral ${ }^{1}$, Monika Sood ${ }^{1}$ and Naseer Ahmed ${ }^{2 *}$ \\ ${ }^{1}$ Division of Food Science and Technology, Sher-e-Kashmir, University of Agricultural Sciences and Technology \\ of Jammu -180009 (J\&K), INDIA \\ ${ }^{2}$ Centre of Food Science and Technology, CCS Haryana Agricultural University, Hisar-125004 (Haryana), INDIA \\ *Corresponding author. E-mail: ewsjammu@gmail.com
}

Received: November 18, 2016; Revised received: May 28, 2017; Accepted: October 10, 2017

\begin{abstract}
Poultry meat is a major source of high biological value protein. The incorporation of fiber in meat helps to enhance its nutritive value with added health benefits that demonstrates a relationship between a diet containing an excess of energy- dense food rich in fats and sugar and the emergence of a range of chronic disease and several others. While studying the effect of fiber incorporation on the functional parameters it was observed that cooking yield (\%) and emulsion stability (\%) significantly decreased and the values were $91.94 \%$ and $91.13 \%$ in control and $87.28 \%$ and $87.01 \%$ in case of $\mathrm{T}_{7}(18 \% \mathrm{KnolKhol}$ powder $)$. The physico chemical analysis revealed that with addition of Knolkhol powder (3\%) level, the pH decreased from 6.31 to 6.26 , TBARS from 0.39 to 0.33 (mg malonaldehyde $/ \mathrm{Kg}$ ), ash content from 2.60 to $2.52 \%$ crude protein 17.15 to $17.10 \%$, where as moisture increased from 66.06 to $67.11 \%$, crude fiber from 0.58 to $0.65 \%$. Coliform were not evident in the stored samples up to 30 days of storage, however psychrophyll count was found after 30 days of storage. The total psychrophillic count in control samples was 0.36 (log cfu/g) which increased to 0.81 (log cfu/g) with addition of $25 \%$ Sweet Corn paste.
\end{abstract}

Keywords: Antioxidant activity, Chicken meat, Dietary fibre,Shelf life, TBARS

\section{INTRODUCTION}

As consumers have become more health conscious, the trend is towards food including meat products with decreased level of fat, cholesterol, salt and caloric content as well as enriched with dietary fibers (Yang et al., 2007). India's consumers prefer to buy freshly butchered chicken meat at open or "wet" markets; such purchases constitute more than 90 percent of total poultry sales volume. Although by contrast processed chicken meat constitutes only around seven to ten percent of total chicken sales volume, it is growing between 15 to 20 percent per year due to the growing middle class (GAIN, 2016). Poultry is a choice meat in India also as it contains less fat and is said to be easily digestible than other meat. Also the price of poultry meat is lower than that of the red meat. Poultry meat occupies a unique

place in human diet by virtue of its specific nutritional characteristics. Undoubtedly, poultry meat is a major source of proteins with high biological value in many countries. Poultry meat is a good source of niacin, riboflavin, thiamine and ascorbic acid as well as sodium $(\mathrm{Na})$, potassium $(\mathrm{K})$, calcium $(\mathrm{Ca})$, iron $(\mathrm{Fe})$, phosphorus (P), sulphur (S) and iodine(I). All these nutritional components have specific function in our body. As compared to other species, the chicken meat is having low fat, less calories, low cholesterol (Kassem and Emara, 2010).Additionally, the chicken meat is getting popular owing to concerns about obesity and diseases related to high fat or low fat versions of their traditional food health organizations all over the world has proposed limits for total fat intake not less than $30 \%$ of the total calories (Koutsopoulos et al., 2008). It has also been advised to reduce the intake of saturated fatty acids and cholesterol a means of preventing cardio vascular heart diseases. Many incidences of people suffering from constipation have been reported throughout the world which is leading to colon cancer. To avoid such problems, incorporation of dietary fibers into poultry meat has become important. Dietary fiberare the key ingredient lacking in the meat products. Addition of some compatible vegetable entity into meat not only reduces its cost but also add some essential vitamins and fiber which are lacking in meat. The Kohlrabi or German turnip (Brassica oleracea) locally called monj, is one of the most commonly eaten vegetables in Jammu and Kashmir (Larssonand Wolk, 2006).

Kohlrabi is notably rich in vitamins and dietary fiber and has negligible amount of fat, cholesterol and act as anti carcinogenic. Fresh kohlrabi stem is rich source of vitamin C (62 mg per $100 \mathrm{~g}$ ). The antioxidant property of kohlrabi helps in prevention from diseases and cancer. Kohlrabi, contains health-promoting phytochemicals such as isothiocyanatessulforaphane, and indole-3-carbinol that are supposed to protect against prostate and colon cancers. Development of pre 
-processed convenient high fibre meat products like meatballs, nuggets etc is considered as potential solution to this concurrent problem. The processed meat products are ready to fry and serve and are gaining importance in the consumer market. The meat balls are one of the readily acceptable value added commutated emulsion based product that is either steamed cooked or consumed after frying of steamed product. Fiber addition in meat products is becoming more common, and dietary fiber addition may effectively increase acceptability by giving meat products higher quality, improving the processing characteristics of meat products, improving the yield of meat products, and lengthening the shelf time (Yanget al., 2017). The objectives of this study are : to ascertain the physico chemical attributes of high fibre meat balls and to study the storage stability of prepared product.

\section{MATERIALS AND METHODS}

Raw material: The chicken meat (broiler hens 6 weeks old) purchased from local market. The body fat was trimmed and deboning of dressed chicken was done manually to remove all tendons and separable connective tissue. The lean meat was packed in polythene bags and stored at frozen conditions at $-18 \pm 2^{0} \mathrm{C}$ until use. Theknolkhol was obtained from local the market of Jammu. Approximately $10 \mathrm{~kg}$ knolkhol was washed with clean water. Knolkhol leaves were separated properly from the bulb and the stems were removed. The leaves and bulbs were partially dried in hot air oven at $40^{\circ} \mathrm{C}$ for half an hour and converted into paste by grinding. The knolkhol paste thus prepared was incorporated at 3, 6, 9, 12, 15 and $18 \%$ levels in the formulation replacing lean meat.

Preparation of chicken meat balls: hicken lean meat was cut into smaller chunks and minced in a Sirman mincer (MOD-TC 32 R10 U.P. INOX, Marsango, Italy). The common salt, vegetable oil, refined wheat flour (maida), nitrite, sodium tripolyphosphate (STPP), spice mixture and condiment mixture were added to weighed meat according to the formulation. Meat emulsion for chicken meatballs was prepared in Sirman Bowl Chopper [MOD C 15 2.8G 4.0 HP, Marsango, Italy]. Minced meat was blended with salt, sodium tripolyphosphate and sodium nitrite for 1.5 minute. Water in the form of crushed ice was added and blending was continued for 1 minute. Refined vegetable oil was added and then blended for another 1 to 2 minutes. This was followed by addition of spice mixture, condiments and other ingredients and again mixed for 1.5 to 2 minutes to get the desired emulsion. Care was taken to keep the end point temperature below $18^{\circ} \mathrm{C}$ by preparing the emulsion in cool hours of morning, and by addition of meat and other ingredients in chilled/ partially thawed form with the addition of crushed ice or ice water.
Moulding of meat balls: pproximately 20-22gm of the emulsion was taken and molded by rolling in hands and giving ball shape. While making the balls 2-3 drops of oil is applied on the palm so that the emulsion doesn't stick to hand while rolling.

Packaging material: The final product chicken meat balls were packed in laminated pouches, sealed and stored under frozen conditions at $-18 \pm 2{ }^{0} \mathrm{C}$ in a deep freezer. The samples were drawn periodically for their physico-chemical, organoleptic analysis during three months of storage at an interval of one month.

Physico-chemical analysis

pH: The $\mathrm{pH}$ of raw mix/emulsion soon after its preparation and cooked meat balls was determined by the method of Keller et al. (1974) with slight modifications. Ten gram of sample was homogenized with 50 $\mathrm{ml}$ distilled water by using pestle and mortar for $1 \mathrm{mi}$ nute. The $\mathrm{pH}$ of the suspension was recorded by immersing combined glass electrode of digital $\mathrm{pH}$ meter (Systronics Digital pH Meter 802, Serial No. 603).

Emulsion stability: Emulsion stability of meat emulsion was determined as per procedure described by Townsend et al. (1968) with some modifications. About $25 \mathrm{~g}$ of samples were placed in polyethylene bags (Size $12 \times 10 \mathrm{~cm}$ ). Bags with samples were weighed and sealed. These bags were immersed in a thermostatically controlled water bath at $80^{\circ} \mathrm{C}$ for 20 minutes. The bags were removed from the water bath, cut open and cooked fluids (fat, water and solids) were drained. The cooked samples were weighed. Loss of weight after cooking was calculated and expressed (in percentage) as an index of ES.

Proximate composition: The moisture, fat, ash, protein and crude fibre content of chicken meat balls, raw and cooked were determined by standard method of (AOAC, 1995).

Cooking yield: The weight of each meat ball was recorded before and after cooking. The cooking yield was calculated and expressed as percentage by the formula (1):

Cooking yield $(\%)=$ Weight of cooked meat ball $/$ Weight of raw meat ball x 100 .

Color Values: Color values were determined in CIE Colour Lab coordinates by using a Hunter Lab Color Quest XE (Hunter associates laboratory, USA). Inside and outside color values of samples were expressed in terms of lightness $\left(\mathrm{L}^{*}\right)$, redness $\left(\mathrm{a}^{*}\right)$ and yellowness $\left(b^{*}\right)$.

Ascorbic acid: Take about 25-30gm of prepared sample containing 100-200mg ascorbic acid. Dilute with $100 \mathrm{ml}$ of meta phosphoric acid solution and mix through an acid washed filter paper (Watman 541). Take 3 samples aliquots containing about $2.0 \mathrm{mg}$ of ascorbic acid, add $5 \mathrm{ml}$ of meta phosphoric acetic acid solution. Make a blank using $7 \mathrm{ml}$ of extracting solution. Titrate blank also by diluting it with water to $n$ the extent of the indophenol solution used in the 
sample.

$$
\text { Ascorbic acid } \mathrm{mg} / 100 \mathrm{gm}=\frac{\text { sample-titre-blankx mg ascorbic acid x wol made }}{\text { Aliquot taken } x \text { weight of sample }}
$$

Thio barbituric acid (TBARS): Thiobarbituric Acid Value of chicken meat balls, during storage was determined using the method of Witte et al. (1970).10 $\mathrm{g}$ of chicken meat balls sample was blended finely with 50 $\mathrm{ml}$ of $20 \%$ TCA in a waring blender/ homogenizer for 2 minutes or with a pestle\& mortar and the resulting slurry was allowed to stand for 10 minutes. The extract was filtered through Whatman filter paper No.42 and 3 $\mathrm{ml}$ of this extract was mixed with equal volume of $0.1 \%(\mathrm{w} / \mathrm{v})$ TBARS reagent in test tube and blank sample was prepared by mixing $3 \mathrm{ml} \mathrm{20 \%}$ TCA with equal volume of $0.1 \%$ TBARS reagent. The content of each test tube was thoroughly mixed and boiled for 35 minutes in a boiling water bath and the test tubes were allowed to cool down. The absorbance was measured at $532 \mathrm{~nm}$ by a spectrophotometer and TBARS value was calculated by comparing the absorbance of test sample with a standard graph prepared by using known concentrations of malonaldehyde. For preparing standard graph, 0.3055 gm of 1,1,3,3 Tetraethoxy Propane (TEP) was dissolved in $100 \mathrm{ml}$ of $95 \%$ absolute alcohol to obtain a concentration of $1 \mathrm{mg}$ malonaldehyde/ $\mathrm{ml}$ and was used as stock solution. To prepare working standard solution of TEP, $0.3 \mathrm{ml}$ of stock solution was diluted to a volume of $100 \mathrm{ml}$ by distilled water. The diluted solution contained $3 \mu \mathrm{g} / \mathrm{ml}$ of malonaldehyde and from that solution a standard graph was prepared by using different concentration of malonaldehyde.

Microbial analysis: Total plate count, Psychrophilic count and Coliform count and Mould count in the sample were determined by method described by APHA (1984). Readymade media (Hi-Media) were used for the analysis.

Sensory evaluation of chicken meat balls: semitrained sensory panel was used to evaluate the sensory attributes viz: appearance, flavour, juiciness, texture and the overall acceptability of fresh and stored samples using 8 point descriptive scale according to the method of Semanetal.(1987).

Statistical analysis: Mean value, standard deviation, analysis of variance were computed using a commercial statistical package SPSS 16 (USA). The data were then compared using Duncan's multiple range tests at appropriate level of significance for pair wise comparison of treatment

\section{RESULTS AND DISCUSSION}

A Perusal of data in Table 1 indicated that fresh chicken meat had $54.35 \%$ moisture, $2.31 \%$ ash content, $0.25 \%$ fibre, $9.25 \%$ fat and $17.10 \%$ protein content. However, ascorbic acid was not found in chicken meat. Knolkhol had $91 \%$ moisture, $1.00 \%$ ash content, 5.6
Table 1. Chemical composition of chicken meat and knolkhol.

\begin{tabular}{lll}
\hline Parameters & Fresh meat & Knolkhol \\
\hline Moisture (\%) & 54.35 & 91.00 \\
Ash (\%) & 2.31 & 1.00 \\
Fiber (\%) & 0.25 & 3.60 \\
Fat (\%) & 9.25 & 0.10 \\
Protein (\%) & 17.10 & 1.70 \\
\hline
\end{tabular}

$\%$ fibre, $0.10 \%$ fat and $1.70 \%$ protein content and 62 $\mathrm{mg} / 100 \mathrm{~g}$ ascorbic acid.

Table 2 indicates significant difference in cooking yield of chicken meat balls in all treatments having different ratios of knolkhol. The maximum value of cooking yield (91.94\%) was recorded in $\mathrm{T}_{1}$ whereas the minimum value $(87.28 \%)$ was recorded in $T_{7}$ (82:18::chicken meat : knolkhol). Decrease in cooking yield might be attributed to the decrease in emulsion stability and due to the high ability of dietary fiber to retain moisture and fat in the matrix. This was found in agreement with Vermaet al. $(2010,2012)$ who observed that there was a decrease in cooking yield of chicken nuggets and chicken meat chips by sodium chloride replacement and apple pulp inclusion. However, the maximum value of emulsion Stability $(91.13 \%)$ was recorded in $\mathrm{T}_{1}$ and the minimum value of emulsion stability $(87.01 \%)$ was recorded in $\mathrm{T}_{7}$. The differences in the emulsion stability were significant. This result is broadly in agreement with the observations of Verma $(2009,2012)$ who observed similar findings in designer chicken nuggets incorporated with high dietary fibre and chicken meat chips.

Hunter colour measurement after addition of knolkhol suggested significant effect on $L^{*}\left(\right.$ lightness), $b^{*}$ (yellowness) and $\mathrm{a}^{*}$ (redness) of chicken meat balls (Table 2). Addition of knolkhol significantly $(\mathrm{P}<0.05)$ decreased the lightness and redness values and the highest score of 19.80 was obtained for $T_{1}$ where as lowest value of 12.57 was obtained for $T_{7}$. Similarly in case of $a^{*}$ values, the max value of 10.42 was obtained for $T_{1}$ where as the lowest value of 7.19 was obtained for $\mathrm{T}_{7}$. However, the colour value for $\mathrm{b}^{*}$ followed $\mathrm{a}$ reverse trend and the value increased with the increasing level of knolkhol in the chicken meat.

The results of moisture content, crude protein and crude fat are summarised in Table 3 . The data revealed that moisture content of meat balls differed significantly $(p<0.05)$ and increased from 66.06 to $68.85 \%$ in sample containing zero \%knolkhol and $18 \%$ knolkhol, respectively during zero day storage. Addition of knolkhol significantly increased ash content from 2.31 $\%$ (zero day) to $2.52 \%$ (90 days) during storage. This is in agreement with Kassem and Emara (2010) and Vermaet al. (2010) who reported that ash percent decreased with the increasing levels of apple pulp and product with $10 \%$ pulp had the lowest ash percent. Crude fat and crude protein was significantly affected 
Ifrah Khursheed et al. / J. Appl. \& Nat. Sci. 9 (4): 2221 - 2227 (2017)

Table 2. Effect of frozen storage $\left(-18 \pm 2^{\circ} \mathrm{C}\right)$ on emulsion stability, cooking yield $(\%)$ and colour values $(\%)$ of knolkhol incorporated chicken meat balls.

\begin{tabular}{lcccccc}
\hline Treatments & $\begin{array}{c}\text { Emulsion stability } \\
(\%)\end{array}$ & $\begin{array}{c}\text { Cooking Yield } \\
(\%)\end{array}$ & \multicolumn{3}{c}{ Colour values } \\
\cline { 4 - 7 } & 91.13 & 91.94 & 19.80 & 10.42 & 11.18 & 13.80 \\
$\mathrm{~T}_{1}$ & 90.96 & 91.88 & 14.03 & 9.14 & 11.93 & 11.70 \\
$\mathrm{~T}_{2}$ & 90.21 & 90.85 & 16.55 & 8.91 & 12.07 & 12.51 \\
$\mathrm{~T}_{3}$ & 87.95 & 89.19 & 14.84 & 7.93 & 12.21 & 11.66 \\
$\mathrm{~T}_{4}$ & 87.30 & 88.34 & 14.00 & 7.78 & 14.00 & 11.93 \\
$\mathrm{~T}_{5}$ & 87.13 & 87.70 & 13.69 & 7.45 & 14.44 & 11.86 \\
$\mathrm{~T}_{6}$ & 87.01 & 87.28 & 12.57 & 7.19 & 18.43 & 12.73 \\
$\mathrm{~T}_{7}$ & 88.81 & 89.60 & 15.07 & 8.40 & 13.47 & \\
Mean & 0.10 & 0.07 & & & & $\mathbf{b}^{*}$ \\
$\mathrm{CD}(\mathrm{p}<0.05)$ & & & & & & \\
\hline
\end{tabular}

Table 3. Effect of frozen storage $\left(-18+2{ }^{\circ} \mathrm{C}\right)$ on moisture $(\%)$, crude protein $(\%)$ and crude fat $(\%)$ content of knolkhol incorporated chicken meat balls.

\begin{tabular}{|c|c|c|c|c|c|c|c|c|c|c|c|c|c|c|c|}
\hline \multirow[b]{2}{*}{$\begin{array}{l}\text { Treat- } \\
\text { ments }\end{array}$} & \multicolumn{5}{|c|}{ Moisture (\%) } & \multicolumn{5}{|c|}{ Crude Protein (\%) } & \multicolumn{5}{|c|}{ Crude Fat (\%) } \\
\hline & 0 day & $\begin{array}{c}30 \\
\text { day }\end{array}$ & $\begin{array}{c}60 \\
\text { day }\end{array}$ & $\begin{array}{c}90 \\
\text { day }\end{array}$ & Mean & 0 day & $\begin{array}{c}30 \\
\text { day }\end{array}$ & $\begin{array}{c}60 \\
\text { day }\end{array}$ & $\begin{array}{c}90 \\
\text { day }\end{array}$ & Mean & $\begin{array}{c}0 \\
\text { day }\end{array}$ & $\begin{array}{c}30 \\
\text { day }\end{array}$ & $\begin{array}{c}60 \\
\text { day }\end{array}$ & $\begin{array}{c}90 \\
\text { day }\end{array}$ & Mean \\
\hline $\mathrm{T}_{1}$ & 66.06 & 65.98 & 65.80 & 65.37 & 65.80 & 17.15 & 17.01 & 16.90 & 16.68 & 16.94 & 13.68 & 13.65 & 13.60 & 13.57 & 13.62 \\
\hline $\mathrm{T}_{2}$ & 67.11 & 67.09 & 67.07 & 66.04 & 66.83 & 17.10 & 16.97 & 16.82 & 16.61 & 16.88 & 13.51 & 13.43 & 13.36 & 13.26 & 13.39 \\
\hline $\mathrm{T}_{3}$ & 67.72 & 67.70 & 67.58 & 67.45 & 67.61 & 17.03 & 16.90 & 16.78 & 16.55 & 16.82 & 13.44 & 13.37 & 13.23 & 13.17 & 13.30 \\
\hline $\mathrm{T}_{4}$ & 67.96 & 67.84 & 67.52 & 67.19 & 67.63 & 16.94 & 16.81 & 16.72 & 16.47 & 16.74 & 12.84 & 12.73 & 12.64 & 12.57 & 12.70 \\
\hline $\mathrm{T}_{5}$ & 68.19 & 68.07 & 67.44 & 67.22 & 67.73 & 16.82 & 16.72 & 16.63 & 16.43 & 16.65 & 12.69 & 12.55 & 12.43 & 12.38 & 12.51 \\
\hline $\mathrm{T}_{6}$ & 68.58 & 68.36 & 68.13 & 67.89 & 68.24 & 16.71 & 16.65 & 16.49 & 16.38 & 16.56 & 12.38 & 12.19 & 12.07 & 12.04 & 12.17 \\
\hline \multirow[t]{2}{*}{$\mathrm{T}_{7}$} & 68.85 & 68.73 & 68.49 & 68.17 & 68.56 & 16.60 & 16.48 & 16.32 & 16.20 & 16.40 & 12.11 & 11.93 & 11.72 & 11.67 & 11.86 \\
\hline & 67.78 & 67.68 & 67.43 & 67.05 & & 16.90 & 16.78 & 16.66 & 16.46 & & 12.95 & 12.84 & 12.72 & 12.67 & \\
\hline $\mathrm{CD}$ & \multicolumn{3}{|c|}{ Treatment } & \multicolumn{2}{|c|}{0.15} & \multicolumn{3}{|c|}{ Treatment } & \multicolumn{2}{|c|}{0.03} & \multicolumn{3}{|c|}{ Treatment } & \multicolumn{2}{|c|}{0.05} \\
\hline$(\mathrm{p}<$ & \multicolumn{3}{|c|}{ Storage } & \multicolumn{2}{|c|}{0.09} & \multicolumn{3}{|c|}{ Storage } & \multicolumn{2}{|c|}{0.06} & \multicolumn{3}{|c|}{ Storage } & \multicolumn{2}{|c|}{0.03} \\
\hline 0.05$)$ & \multicolumn{3}{|c|}{ Treatment X Storage } & \multicolumn{2}{|c|}{0.08} & \multicolumn{3}{|c|}{ Treatment X Storage } & \multicolumn{2}{|c|}{0.09} & \multicolumn{3}{|c|}{ Treatment X Storage } & \multicolumn{2}{|c|}{0.10} \\
\hline
\end{tabular}

Table 4. Effect of frozen storage $\left(-18 \pm 2^{\circ} \mathrm{C}\right)$ on Ash (\%), Crude fibre (\%) and Ascorbic acid (mg/100g) content of knolkhol incorporated chicken meatballs.

\begin{tabular}{|c|c|c|c|c|c|c|c|c|c|c|c|c|c|c|c|}
\hline \multirow[b]{2}{*}{$\begin{array}{l}\text { Treat- } \\
\text { ments }\end{array}$} & \multicolumn{5}{|c|}{ Ash (\%) } & \multicolumn{5}{|c|}{ Crude fibre (\%) } & \multicolumn{5}{|c|}{ Ascorbic acid (mg/100g) } \\
\hline & 0 day & $\begin{array}{c}30 \\
\text { day }\end{array}$ & $\begin{array}{c}60 \\
\text { day }\end{array}$ & $\begin{array}{c}90 \\
\text { day }\end{array}$ & Mean & $\begin{array}{c}0 \\
\text { day }\end{array}$ & $\begin{array}{c}30 \\
\text { day }\end{array}$ & $\begin{array}{c}60 \\
\text { day }\end{array}$ & $\begin{array}{c}90 \\
\text { day }\end{array}$ & Mean & 0 day & $\begin{array}{c}30 \\
\text { day }\end{array}$ & $\begin{array}{c}60 \\
\text { day }\end{array}$ & $\begin{array}{c}90 \\
\text { day }\end{array}$ & Mean \\
\hline $\mathrm{T}_{1}$ & 2.60 & 2.69 & 2.76 & 2.89 & 2.74 & 0.58 & 0.62 & 0.65 & 0.69 & 0.64 & 6.30 & 6.24 & 6.20 & 2.13 & 5.22 \\
\hline $\mathrm{T}_{2}$ & 2.52 & 2.60 & 2.67 & 2.75 & 2.64 & 0.65 & 0.67 & 0.73 & 0.76 & 0.70 & 13.42 & 13.35 & 13.30 & 13.20 & 13.32 \\
\hline $\mathrm{T}_{3}$ & 2.40 & 2.45 & 2.52 & 2.60 & 2.49 & 0.68 & 0.75 & 0.81 & 0.83 & 0.77 & 15.98 & 15.95 & 15.90 & 15.81 & 15.91 \\
\hline $\mathrm{T}_{4}$ & 2.31 & 2.38 & 2.44 & 2.52 & 2.41 & 0.76 & 0.84 & 0.91 & 0.94 & 0.86 & 17.13 & 17.05 & 17.01 & 16.90 & 17.02 \\
\hline $\mathrm{T}_{5}$ & 2.22 & 2.29 & 2.35 & 2.41 & 2.32 & 0.79 & 0.90 & 1.02 & 1.05 & 0.94 & 19.54 & 19.50 & 19.42 & 19.35 & 19.45 \\
\hline $\mathrm{T}_{6}$ & 2.15 & 2.20 & 2.26 & 2.30 & 2.23 & 0.90 & 0.96 & 1.05 & 1.12 & 1.01 & 21.84 & 21.81 & 21.74 & 21.70 & 21.77 \\
\hline \multirow[t]{2}{*}{$\mathrm{T}_{7}$} & 1.99 & 2.05 & 2.10 & 2.16 & 2.08 & 0.94 & 1.02 & 1.13 & 1.23 & 1.08 & 23.48 & 23.43 & 23.38 & 23.30 & 23.40 \\
\hline & 2.31 & 2.38 & 2.44 & 2.52 & & 0.76 & 0.82 & 0.90 & 0.95 & & 16.81 & 16.76 & 16.71 & 16.06 & \\
\hline $\mathrm{CD}$ & \multicolumn{3}{|c|}{ Treatment } & \multicolumn{2}{|r|}{0.04} & \multicolumn{3}{|c|}{ Treatment } & \multicolumn{2}{|c|}{0.04} & \multicolumn{3}{|c|}{ Treatment } & \multicolumn{2}{|c|}{1.04} \\
\hline$(\mathrm{p}<$ & \multirow{2}{*}{\multicolumn{3}{|c|}{ Storage }} & \multicolumn{2}{|r|}{0.03} & \multicolumn{3}{|c|}{ Storage } & \multicolumn{2}{|c|}{0.03} & \multicolumn{3}{|c|}{ Storage } & \multicolumn{2}{|c|}{0.03} \\
\hline 0.05$)$ & & \multicolumn{2}{|c|}{ Treatment X Storage } & \multicolumn{2}{|r|}{ N.S } & \multicolumn{3}{|c|}{ Treatment X Storage } & \multicolumn{2}{|c|}{ N.S } & \multicolumn{3}{|c|}{ Treatment X Stor } & \multicolumn{2}{|c|}{0.09} \\
\hline
\end{tabular}

by storage period which followed a decreasing trend. The highest mean crude fat of $12.95 \%$ was recorded at zero month storage which decreased to $12.67 \%$ after 90 days storage. This decrease in fat content could be attributed to the increase in the level of knolkhol. These results agree with those reported by FernandezGines et al. (2004) in which the addition of raw and cooked Albedo at any concentration and 2.5 or $5.0 \%$ decreased fat content in sausages. Similar results were also reported by Valeria et al. (2008) and Kassem and Emara (2010).

The results pertaining to ash, crude fibre and ascorbic acid contents as affected by addition of knolkhol are summarized in Table 4. Crude fibre and ascorbic acid significantly increased with addition of knolkhol whereas storage had significant decreasing effect on ascorbic acid. The Crude fibre (\%) and ascorbic acid $(\mathrm{mg} / 100 \mathrm{~g})$ in fresh chicken meat balls increased from 0.58 to 0.94 and 6.30 to 23.48 after addition of $18 \%$ knolkhol. However, the mean scores for ascorbic acid decreased from 16.81 to $16.06 \mathrm{mg} / 100 \mathrm{~g}$ after 90 days of storage. This was found in agreement with Verma et al. (2009) who also observed a significant $(\mathrm{P}<0.05)$ increase in dietary fibre content in apple pulp incorporated chicken nuggets. Similar results were reported by Verma et al. (2010) and Pinho et al. (2011)

The mean value of $\mathrm{pH}$ (Table 5) decreased from 6.11 at zero day of storage to 5.90 at 90 days of storage. The maximum level $\mathrm{pH} 6.31 \%$ was recorded in $\mathrm{T}_{1}$ and the minimum $\mathrm{pH}$ of $5.87 \%$ was recorded in $\mathrm{T}_{7}$. As the 
Table 5. Effect of frozen storage $\left(-18 \pm 2^{\circ} \mathrm{C}\right)$ on $\mathrm{pH}$, Thio barbituric acid (mg malonaldehyde/ $\mathrm{Kg}$ ) and overall acceptability of knolkhol incorporated chicken meat balls.

\begin{tabular}{|c|c|c|c|c|c|c|c|c|c|c|c|c|c|c|c|}
\hline \multirow{2}{*}{$\begin{array}{l}\text { Treat- } \\
\text { ments }\end{array}$} & \multicolumn{5}{|c|}{ pH } & \multicolumn{5}{|c|}{$\begin{array}{c}\text { Thio barbituric acid } \\
\text { (mg malonaldehyde/Kg) }\end{array}$} & \multicolumn{5}{|c|}{ Overall acceptability } \\
\hline & 0 day & $\begin{array}{c}30 \\
\text { day }\end{array}$ & $\begin{array}{c}60 \\
\text { day }\end{array}$ & $\begin{array}{c}90 \\
\text { day }\end{array}$ & Mean & 0 day & $\begin{array}{c}30 \\
\text { day }\end{array}$ & $\begin{array}{c}60 \\
\text { day }\end{array}$ & $\begin{array}{c}90 \\
\text { day }\end{array}$ & $\begin{array}{c}\text { Mea } \\
\text { n }\end{array}$ & $\begin{array}{c}0 \\
\text { day }\end{array}$ & $\begin{array}{c}\text { 30 } \\
\text { day }\end{array}$ & 60 day & 90 day & $\begin{array}{c}\text { Mea } \\
\text { n }\end{array}$ \\
\hline $\mathrm{T}_{1}$ & 6.31 & 6.25 & 6.19 & 6.14 & 6.22 & 0.39 & 0.47 & 0.73 & 0.89 & 0.62 & 7.34 & 7.23 & 7.05 & 6.85 & 7.12 \\
\hline $\mathrm{T}_{2}$ & 6.26 & 6.21 & 6.16 & 6.11 & 6.19 & 0.33 & 0.44 & 0.64 & 0.85 & 0.56 & 7.39 & 7.23 & 7.04 & 6.88 & 7.13 \\
\hline $\mathrm{T}_{3}$ & 6.19 & 6.15 & 6.10 & 6.04 & 6.12 & 0.29 & 0.42 & 0.60 & 0.80 & 0.54 & 7.44 & 7.28 & 7.07 & 6.92 & 7.18 \\
\hline $\mathrm{T}_{4}$ & 6.13 & 6.09 & 6.03 & 5.97 & 6.06 & 0.25 & 0.40 & 0.57 & 0.76 & 0.50 & 7.46 & 7.24 & 7.11 & 6.97 & 7.19 \\
\hline $\mathrm{T}_{5}$ & 6.05 & 6.01 & 5.95 & 5.91 & 5.98 & 0.23 & 0.38 & 0.51 & 0.70 & 0.46 & 7.19 & 7.03 & 6.87 & 6.75 & 6.96 \\
\hline $\mathrm{T}_{6}$ & 5.98 & 5.85 & 5.69 & 5.62 & 5.79 & 0.20 & 0.35 & 0.49 & 0.65 & 0.43 & 6.99 & 7.31 & 6.70 & 6.52 & 6.88 \\
\hline \multirow[t]{2}{*}{$\mathrm{T}_{7}$} & 5.87 & 5.79 & 5.57 & 5.50 & 5.68 & 0.19 & 0.32 & 0.45 & 0.61 & 0.40 & 6.89 & 6.70 & 6.56 & 6.32 & 6.62 \\
\hline & 6.11 & 6.05 & 5.96 & 5.90 & & 0.27 & 0.41 & 0.57 & 0.75 & & 7.24 & 7.15 & 6.91 & 6.74 & \\
\hline $\mathrm{CD}$ & \multicolumn{3}{|c|}{ Treatment } & \multicolumn{2}{|c|}{0.04} & \multicolumn{3}{|c|}{ Treatment } & \multicolumn{2}{|c|}{0.03} & \multicolumn{3}{|c|}{ Treatment } & \multicolumn{2}{|l|}{0.04} \\
\hline$(\mathrm{p}<$ & \multicolumn{3}{|c|}{ Storage } & \multicolumn{2}{|c|}{0.03} & \multirow{2}{*}{\multicolumn{3}{|c|}{ Storage }} & \multicolumn{2}{|c|}{0.04} & \multicolumn{3}{|c|}{ Storage } & \multicolumn{2}{|l|}{0.09} \\
\hline 0.05$)$ & \multicolumn{3}{|c|}{ Treatment X Storage } & \multicolumn{2}{|c|}{0.08} & \multicolumn{2}{|c|}{ Treatment X Storage } & & \multicolumn{2}{|c|}{0.07} & \multicolumn{3}{|c|}{ Treatment X Storage } & \multicolumn{2}{|l|}{0.08} \\
\hline
\end{tabular}

Table 6. Effect of frozen storage $\left(-18 \pm 2^{\circ} \mathrm{C}\right)$ on Phycrophilic count, Total plate count and Coliform count content of knolkhol incorporated chicken meat balls.

\begin{tabular}{|c|c|c|c|c|c|c|c|c|c|c|c|c|}
\hline \multirow[b]{2}{*}{$\begin{array}{l}\text { Treat- } \\
\text { ments }\end{array}$} & \multicolumn{4}{|c|}{ Phycrophilic count (log efu/g) } & \multicolumn{4}{|c|}{ Total plate count (log cfu/g) } & \multicolumn{4}{|c|}{ Coliform count $(\log \mathrm{cfu} / \mathrm{g})$} \\
\hline & 0 day & 30 day & 60 day & 90 day & 0 day & $\begin{array}{c}30 \\
\text { day }\end{array}$ & $\begin{array}{c}60 \\
\text { day }\end{array}$ & $\begin{array}{c}90 \\
\text { day }\end{array}$ & 0 day & 30 day & 60 day & 90 day \\
\hline $\mathrm{T}_{1}$ & ND & 0.36 & 0.70 & 1.44 & 0.49 & 0.61 & 1.52 & 2.49 & ND & ND & ND & ND \\
\hline $\mathrm{T}_{2}$ & ND & 0.42 & 0.76 & 1.50 & 0.52 & 0.65 & 1.57 & 2.55 & ND & ND & ND & ND \\
\hline $\mathrm{T}_{3}$ & ND & 0.48 & 0.82 & 1.54 & 0.54 & 0.70 & 1.61 & 2.60 & ND & ND & ND & ND \\
\hline $\mathrm{T}_{4}$ & ND & 0.54 & 0.89 & 1.62 & 0.57 & 0.76 & 1.66 & 2.65 & ND & ND & ND & ND \\
\hline $\mathrm{T}_{5}$ & ND & 0.60 & 0.95 & 1.73 & 0.59 & 0.81 & 1.70 & 2.70 & ND & ND & ND & ND \\
\hline $\mathrm{T}_{6}$ & ND & 0.65 & 1.01 & 1.85 & 0.62 & 0.84 & 1.75 & 2.75 & ND & ND & ND & ND \\
\hline $\mathrm{T}_{7}$ & ND & 0.73 & 1.09 & 1.93 & 0.65 & 0.86 & 1.82 & 2.79 & ND & ND & ND & ND \\
\hline & - & 0.54 & 0.89 & 1.66 & 0.57 & 0.75 & 1.66 & 2.65 & - & - & - & - \\
\hline
\end{tabular}

storage period advanced, there was significant decrease in pH. Viuda-Martos et al. (2010), Verma et al. (2010) and Verma et al. (2012) gave similar findings for chicken meat chips. The major problem during subsequent storage of ready to eat meat products is lipid oxidation. The data revealed that thiobarbituric acid value of meat balls differed significantly in all treatments as well as during storage period. The maximum value of 0.39 (mg malonaldehyde $/ \mathrm{kg}$ ) was observed in $\mathrm{T}_{1}$ which decrease to 0.19 ( $\mathrm{mg}$ malonaldehyde $/ \mathrm{kg}$ ) in $\mathrm{T}_{7}$. The results for the interaction between Treatment x Storage were also significant. Other workers also reported progressive increase in lipid oxidation during storage period resulting in the increase in thiobarbituric acid values (Kumar and Sharma, 2003; Modi et al., 2003).Devatkal et al., 2014 reported that addition of pomegranate peel extract as a natural antioxidant to reduce TBARS values in control and pressure treated chicken nuggets. At the beginning of storage, the maximum over all acceptability score of 7.46 was recorded for $\mathrm{T}_{4}$ where as the minimum score of 6.89 was observed for $\mathrm{T}_{7}$. As the storage period advanced, there was decrease in over all acceptability score. The mean score for over acceptability decreased from 7.24 to 6.74 after 90 days of storage. The results of the study were in agreement with the findings of Devatkal and Mendiratta (2001), Naveena et al. (2006) and Dasiewicz and Urcus (2009).

Total plate count (Table 6) increased significantly from day 0 to 90 days in control and treated products.
On zero daythe minimum Total plate count $(0.49 \mathrm{log}$ $\mathrm{cfu} / \mathrm{g}$ ) was recorded in $\mathrm{T}_{1}$ and the maximum $(0.65 \mathrm{log}$ $\mathrm{cfu} / \mathrm{g}$ ) was recorded in $T_{7}$. There was significant increase in the Total plate countofknolkhol blended chicken meat balls during storage. The mean value of Total plate count increased from $0.57 \mathrm{log} \mathrm{cfu} / \mathrm{g}$ at zero day of storage to $2.65 \mathrm{log} \mathrm{cfu} / \mathrm{g}$ after 90 days of storage.Fernandez-Lopez et al. (2008) also observed the similar increase in total plate count while studying the quality attributes and shelf life of chicken nuggets extended with rice flour. Similar findings were reported by (Kumar et al., 2007); Kumar et al. (2010), ViudaMartos et al. (2010)and Devatkal et al.(2014). The psychrophillic count was not found in freshly prepared sample and were evident after 30 days storage under frozen conditions. The mean value of psychrophilic count increased from $0.54 \mathrm{log} \mathrm{cfu} / \mathrm{g}$ at 30 day of storage to $1.66 \log \mathrm{cfu} / \mathrm{g}$ at 90 days of storage. The counts were within permissible limits as reported by Cremer and Chipley (1977) in cooked meat products. Vedamurthy (1998) reported gradual increase in psychrophillic count from 0 to 20 days in low fat chevonsausages.

No Coliform count were evident in the chicken meat balls samples stored at frozen temperature $\left(-18 \pm 2{ }^{\circ} \mathrm{c}\right)$ upto 90 days. Thecoliform count was not detected throughout storage period of 90 days under frozen condition at $18+2^{\circ} \mathrm{C}$. Modi et al. (2007) studied the quality changes during the storage of dehydrated chicken kebab mix stored at ambient temperature (27 
$\pm 2{ }^{\circ} \mathrm{C}$ ) for 6 months and reported that kabab mix was microbiologically safe as indicated by low bacterial counts and absence of coliform throughout the storage period of 6 months. Similar findings were observed by, Andresaet al. (2006) and Bhat et al. (2011).

\section{Conclusion}

Thus, it can be concluded from the present study that good quality chicken meat balls can be prepared from chicken meat incorporated with knolkhol. Knolkholupto $9 \%$ can be added into chicken meat for the preparation of chicken meat balls with enhanced crude fibre contents, low fat, low TBARS values and higher overall acceptability with extended life under refrigerated conditions $\left(3\right.$ months at $\left.-18 \pm 2{ }^{\circ} \mathrm{C}\right)$. Therefore, processing of chicken meat to fibre rich value added products contribute to sustained demand for meat and efficient marketing of meat to earn reasonable returns by the processors. Such products can be formulated for consumers who are more health conscious and follow the trend of including meat products with decreased level of fat, cholesterol, salt and caloric content as well as enriched with dietary fibers.

\section{REFERENCES}

Andresa, M.E., Garcia, N.E. and Zaritzkya, A.N. (2006).Storage stability of low-fat chicken sausages. Journal of Food Engineering, 72(4): 311-319

AOAC (1995). Official methods of analysis of $15^{\text {th }}$ edition. Association of Analytical Chemists, Washington, D.C.

APHA (1984). Compendium of Methods for the Microbiological Examination of Foods, 2nd ed. American Public Health Association, Washington, DC

Bhat, Z.F and Pathak, V. (2011). Effect of mung bean (vigna radiate) on the quality haracteristics of oven roasted chicken seekh kababs. FleischwirtschaftInternational,6:58-60.

Cremer, M. L. and Chipley, J. R. (1977). Satelite food service system: Time and temperatureand microbiological and sensory quality of precooked frozen hamburger patties. Journal of Food Protection, 40: 603-607.

Dasiewicz, K. and Urcus, P. (2009). Influence of addition of fibre preparations on quality of added water meat block products. RocznikiInstytutuPrzemystuMiesnegoTtuszczowego,47(2):86-94

Devatkal, S., Anurag, A., Jaganath, B. And Rao, S. (2014). Microstructure, microbial profile and quality characteristics of high-pressure-treated chicken nuggets. Food Science and Technology International. 1-11.

Devatkal, S and Mendiratta, S.K. (2001). Use of calcium lactate with salt phosphate and alginate calcium gel in restructures pork rolls. Meat Science,58: 371-379

Fernandez-Gines, J.M., Fernandez-Lopez, J., Sayas-Barbera, E., Sendra, E. and Perez-Alvarez, J.A. (2004). Lemon albedo as a new source of dietary fiber: application to bologna sausages. Meat Science, 67: 7-13.

Fernandez-Lopez, J., Sendra, E., Sayas-Barbera, E., Navarro, C. and Perez-Alvarez, J.A. (2008). Physico-chemical and microbiological profiles of "salchichon" (Spanish dry - fermented sausage) enriched with orange fiber.
Meat Science, 80: 410-417.

GAIN (2016). Poultry and Poultry Products Annual 2016. USDA Foreign agriculture services.

Kassem, M. A., Emara, M. M. T. (2010). Quality and acceptability of value added beef burger. World Journal of Dairy and Food Sciences, 5(1):14-20.

Keller,S.E.,G.C.Skelly and J.C.Acton. (1974).Effect of meat particles size and casing diameter on summer sausage properties during drying. Journal Milk Food Technology, 37:10-106

Koutsopoulos, D.A., Koutsimanis, G.E. and Bloukas, J.G. (2008). Effect of carrageen Level and packaging during ripening on processing and quality characteristics of Low-fat fermented sausages produced with olive oil. Meat Science, 79:188-197.

Kumar, M. and Sharma, B. D. (2003). Soy protein as fat replacer. Fleischwirtschaft International, 83 (4):54-58.

Kumar, R. R., Sharma, B.D., Kumar, M. C. and Biswas, A.K. (2007). Storage quality and shelf life of vacuumpackaged extended chicken patties. Journal of Muscle Foods, 18(30):253-263

Larsson, S.C and Wolk, A. (2006). Meat consumption and risk of colorectal cancer: A meta analysis of prospective studies. International Journal of Cancer, 119:26572664.

Modi, V. K., Mahendrakar, N. S., Rao, N. D. and Schindra, N. M. (2003). Quality of buffalo meat burger containing legume flours as binders. Meat Science, 66: 144-149.

Modi, V. K., Sachindra, N. M., Nagegowda, P., Mahendrakar. N. S., and Roa, D. N. (2007). Quality changes during the storage of dehydrated chicken kebab mix. International of Food Science and Technology, 42: 827 -835 .

Naveena, B.M., Muthukumar, M., Sen, A.R., Babji, Y and Murthy, T.R. K. (2006).Quality characteristics and storage stability of chicken patties with finger millet flour. Journal of Muscle Foods, 17: 92-104.

Pinho, L.X., Afonso, M.R.A., Carioca, J.O.B., Costa, J.M.C. and Ramos, A.M. (2011).The use of cashew apple residue as source of fiber in low fat hamburgers. Ciencia e Technologia de Alimentos,31 (4): 941-945.

Seman, D.L., Moddy, W.G., Fox, J.D and Gay, N. (1987). Influence of hot and cold deboning on the palatability, textural and economic traits of restructured beef steaks. Journal of Food Science, 52 : 879-882.

Townsend, W. E., Witnauer, L. P., Riloff, J. A. and Swift, C. E. (1968). Comminuted meat emulsion. Differential thermal analysis of fat transition. Food Technology, 22: 319- 323

Valeria, S., Eim, S. S., Carmon, R. and Antoni, F. (2008). Effect of addition of carrot dietary fibres on the ripening process of dry fermented sausages (sobrassada). Meat Science, 80: 173-182.

Vedamurthy, C.B. (1998).Utilisation of collagen isolated from skin for production of low-fat sausages. M.V.Sc. Thesis. IVRI Izatnagar, India.

Verma, A. K., Anjaneyulu, A. S. R., Thomas, R. and Kondaiah, N. (2009). Effect of different fats on the quality of goat meat patties incorporated with full-fat soy paste. Journal of Muscle Foods, 20(1):37-53.

Verma, A. K., Sharma, B. D. and Banerjee, R. (2010). Effect of sodium chloride replacement and apple pulp inclusion on the physico-chemical, textural and sensory prop- 
Ifrah Khursheed et al. / J. Appl. \& Nat. Sci. 9 (4): 2221 - 2227 (2017)

erties of low fat chicken nuggets. Food Science and Technology, 43(4):715-719.

Verma, A.K., Ritupama, B. and Sharma, B.D. (2012). Quality of low fat chicken nuggets: Effect of sodium chloride replacement and added chicken (Cicer arietinum L) hull flour. Asian-Australian Journal of Animal Science, 25 (2):29I-298

Viuda-Martos,M., Ruiz-Navajas, Y., Fernandez-Lopez J and Perez,-Alvarez, J.A. (2010). Effect of orange dietary fiber, oregano oil and packaging conditions on shelf-life of bologna sausages. Food Control, 21: 436-443.
Yang ,H.S., Choi, S.G., Jeon, J.T., Park, G.B. and Joo, S.T. (2007). Textural and sensory properties of low-fat pork sausages with added hydrated oat-meal and tofu as texture modifying agents. Meat Science,75: 283-289.

Yang, Y., Sen Ma.,Wang, X. and Zheng, X. (2017). Modification and application of dietary fiber in foods. Journal of Chemistry, 8-15.

Witte, V. C., Krause, G. F. and Bailey, M. E. (1970). A New Extraction Method for Determining 2Thiobarbituric Acid Values of Pork and Beef during Storage. Journal of Food Science, 35, 582-585. 